DOI: https://doi.org/10.30525/978-9934-26-081-0-13

\title{
BUDGET POLICY AS A TOOL FOR ECONOMIC DEVELOPMENT OF TERRITORIES
}

\author{
Radionov Yurii \\ Doctor of Economic Sciences, \\ Head of the International Standards Adaptation \\ and Implementation Department, \\ Accounting Chamber of Ukraine \\ Kyiv, Ukraine \\ ORCID: https://orcid.org/0000-0002-1691-1090 \\ Reseacher ID: $A A V-3875-2020$
}

The needs of communities are the basis for the formation of both regional and budgetary policies. The latter should stimulate the socioeconomic development of the area, increase its economic and tax potential, ensure the growth of domestic sources of financial resources. Each country develops its own algorithm and uses effective tools for redistribution of budget resources between levels of the budget system to ensure the appropriate level of providing the population with quality public goods, social services.

The issue of formation and development of regions, their financial and economic component becomes especially relevant in the current conditions of economic transformation, as it directly affects the socioeconomic condition of the country.

One of the key concepts in the study of theoretical approaches to regional development is the term «region». Methodological approaches to defining the essence of the concept of «region» and the problems of regional development are not constant, but evolve in the process of changing economic reality: from classical (where the region is the accumulation of natural resources, population, means of production, etc.) to modern theories (where the region is multifunctional system with an innovative vector of development) [1, p. 34-35].

According to Romanyuk S.A., the region is the largest administrativeterritorial unit of the subnational level, which has elected government, legal independence and its own budget [2, p. 3]. 
Thus, the Law of Ukraine "On Stimulating the Development of Regions» states that the region is the territory of the Autonomous Republic of Crimea, oblasts, cities of Kyiv and Sevastopol [3].

It should be noted that the dynamics of sustainable development of regions is influenced by regional policy, which reflects the combination of a set of interests with the goals of socio-economic development of the state, its priorities, important social tasks. The region as a holistic, systemic formation is a complex network of special functions and goals, opportunities and limitations, development of industrial, agricultural, social, budgetary policy in a single territory. An effective socio-economic policy for the implementation of each region is to combine links with different territorial and administrative units, taking into account specific features and defining clear, priority tasks for its development.

In addition, the dynamics of regional development is influenced by the clear division of powers between the central executive power and local governments.

The local budget is the basis of financial independence of local governments, and a good reason for its emergence is the need to provide citizens with certain public goods and services.

In economic essence, local budgets are an integral part of the budget system of the state, outline economic relations between individuals, businesses and the territorial community, aimed at forming a fund for the needs of the community, improving the welfare of citizens, socioeconomic development [4, p. 125].

Local budgets provide funds to finance activities and programs of socio-economic development of the territory. The criterion for classifying the budget as «local» is not administrative-territorial affiliation, but a form of self-organization of citizens, ie belonging to the relevant community.

Regional policy, as an important component of the continuation of national economic policy, should promote the effective use of internal reserves of each district, region to increase the tax capacity of the area, increase local budget revenues.

For the purpose of economic growth of territories, the primary task is to identify shortcomings and problems that negatively affect the sustainability of the socio-economic condition of administrative-territorial 
units, strengthening their budget potential using local resource reserves, primarily focusing on recreational, natural and other features is in this area.

The interests of the state and the region must be clearly delineated, have a clear hierarchical structure, and complement each other with appropriate sources of funding.

The current problem of fiscal policy is the efficient and equitable redistribution of GDP between those regions that are stronger financially and those that do not have sufficient funds to address the pressing problems of the territory [4, p. 128].

Unfortunately, the current budget policy of Ukraine does not yet create the preconditions for proper socio-economic development in all regions of the country, which is reflected in the development of the whole country and living standards.

Implementing the budget policy, the state uses various financial instruments, levers and methods to significantly improve and influence the indicators of socio-economic development of its territories. Reducing the number of unproductive and inefficient budget expenditures contributes to the optimization of the expenditure side of local budgets, which affects the level of real economic growth of individual territories and the state as a whole.

Fiscal policy as a component of financial and national economic policy should play an important role in the economic growth of regions, by stimulating local budgets to strengthen their financial potential. To assist in the implementation of the structural restructuring of the regional economy, to ensure current socio-economic transformations in accordance with the objectives and goals of the development strategy of each administrative-territorial unit.

In modern conditions, there is an urgent need to strengthen the role of fiscal policy in promoting sustainable socio-economic development of regions, regulation of socio-economic processes, the principles of revenue generation and the use of budget expenditures. To analyze the existing natural and economic, demographic, recreational potential, clarify regional concepts of socio-economic development of territories, methods of 
stimulating and supporting local entrepreneurship, expanding opportunities for potential investors.

Sustainable socio-economic development of regions depends on the effectiveness of regional, including budgetary policy, the use of mechanisms to stimulate budgetary development of regions, priorities and needs of the local community.

Effective state regional policy should be based on effective budget planning, financial equalization of regions on objective criteria, so that each administrative-territorial unit has the opportunity to implement its own regional policy taking into account national interests, as well as the ability to raise social standards.

The state of socio-economic development of Ukraine requires strengthening the role of local governments in the integrated development of territories. Search for effective tools for managing budget funds, improving methods of using financial resources. Financial decentralization is one of the important conditions for ensuring the viability of local governments, as it increases the opportunities and impact on the development of the controlled area, better performance, more careful coordination of expenditures with local needs and preferences.

Rationalization of budget policy should ensure the balance of private interests, the state, regions and on this basis to promote socio-economic development of territories, which will ensure its efficiency and effectiveness, to meet the demands of residents of individual territories.

Modern regional policy should be based on effective budget planning, financial equalization of regions on objective criteria, so that each administrative-territorial unit has the opportunity to implement its own regional policy, taking into account national interests, as well as the opportunity to raise social living standards. As an important component of the continuation of national economic policy, regional policy should promote the effective use of internal reserves of each district, region to increase the tax capacity of the area, increase local budget revenues.

The problems of filling local budgets with financial resources should be solved by the reform of local self-government bodies, which began in Ukraine in 2015. At the same time, local governments must learn to effectively use local reserves for the development of regions, create new 
enterprises in the field of information and communication technologies, develop rural and industrial tourism, optimize the local budget structure, manage and use budget funds in priority areas of socio-economic development. territories, using, inter alia, the program-target method of budgeting.

\section{References:}

1. Wozniak G.V. (2015) Regional development; essence and methodological basis. Regional economy. № 3. P. 34-43.

2. Romanyuk S.A. (2001) Regional Development Policy in Ukraine: Current Status and New Opportunities: Regional Studies. Kyiv: UDAU, 112 p.

3. Verhovna Rada of Ukraine (2005) Zakon Ukraini vid 08.09.2005p. № 2850-IV "Pro stimulyuvan'ya rozvitku regioniv" [Law of Ukraine of September 8, 2005 № 2850-IV «On stimulating the development of regions»]. Available at: https://zakon.rada.gov.ua/laws/show/2850-15\#Text (accessed 19 May 2021). (in Ukrainian)

4. Radionov Yu.D. (2020) Budget policy to stimulate socio-economic development of regions. Anti-Crisis Management: State, Region, Enterprise. Collective monograph. Riga, Latvia: "Publishing House "Baltija Publishing". P. 122-137. 